\title{
Sosialisasi dan Pendampingan Pengembangan Materi Pembelajaran IPA Berbasis Metakognisi pada Mahasiswa Magister Pendidikan IPA Universitas Mataram
}

\author{
Wildan*, Dwi Laksmiwati, I Nyoman Loka, Supriadi
}

Pendidikan Kimia, FKIP, Universitas Mataram, Mataram

wildanfkip@unram.ac.id

\begin{abstract}
Community service activities have been carried out for master students of Science Education at the University of Mataram which aimed to provide understanding to students about the development of science teaching materials that can develop students' metacognition. Teaching materials that are able to develop metacognitive abilities are needed by students in the current era of globalization. With the ability of metacognition, it will raise students' awareness of what they really know and one's cognition-regulation functions to regulate their cognitive activities effectively. Knowledge-cognition contains declarative, procedural, and conditional knowledge, while metacognition skills include four skills, namely problem solving skills, decision-making skills, critical thinking skills, and creative thinking skills. Activity participants can understand the material presented which was shown by the ability to answer questions during the discussion. An understanding of proper metacognition was also measured by its ability to fill out a questionnaire that was distributed after the service was complete. A good understanding of metacognition is expected to be a guide in developing metacognition-based teaching materials so that students can develop metacognition abilities.
\end{abstract}

Keywords: development; teaching materials; metacognition; self awareness

\begin{abstract}
Abstrak
Kegiatan pengabdian kepada mahasiswa magister Pendidikan IPA Universitas Mataram bertujuan untuk memberikan pemahaman kepada mahasiswa tentang pengembangan bahan ajar IPA yang dapat mengembangkan metakognisi siswa. Bahan ajar yang mampu mengembangkan kemampuan metakognisi sangat dibutuhkan oleh siswa pada era globalisasi saat ini. Dengan kemampuan metakognisi akan memunculkan kesadaran siswa tentang apa yang sesungguhnya diketahuinya dan regulasi-kognisi yang dimiliki seseorang berfungsi mengatur aktivitas kognisifnya secara efektif. Pengetahuan-kognisi memuat pengetahuan deklaratif, prosedural, dan kondisional, sedang kemampuan metakognisi meliputi empat keterampilan, yaitu ketrampilan pemecahan masalah, keterampilan pengambilan keputusan, keterampilan berpikir kritis, dan keterampilan berpikir kreatif. Peserta kegiatan dapat memahami materi yang disampaikan yang ditunjukkan dengan kemampuan menjawab pertanyaan ketika diskusi. Pemahaman tentang metakognisi yang tepat juga terukur dari kemampuannya mengisi angket yang disebar setelah pengabdian selesai. Pemahaman yang baik tentang metakognisi diharapkan dapat menjadi panduan dalam mengembangkan bahan ajar berbasis metakognisi sehingga dapat mengembangkan kemampuan metakognisi siswa.
\end{abstract}

Kata Kunci: pengembangan; bahan ajar; metakognisi; kesadaran diri 


\section{PENDAHULUAN}

Kegiatan pembelajaran tidak terlepas dari keterlibatan bahan ajar. Bahan ajar merupakan arahan terhadap proses pembelajaran yang akan dilaksanakan (Kelana \& Pratama, 2019). Bahan ajar dapat berupa media cetak maupun elektronik yang diharapkan dapat meningkatkan pemahaman siswa pada materi pelajaran yang akan diajarkan (Hernawan et al., 2012). Pembelajaran kimia telah didukung oleh bahan ajar. Akan tetapi, bahan ajar yang selama ini digunakan adalah buku cetak, artikel-artikel atau LKS. Bahan ajar ini perlu dimanfaatkan secara maksimal baik oleh guru maupun siswa (Ramdoniati et al., 2019).

Bahan ajar dapat memudahkan guru dan siswa dalam proses pembelajaran, guru perlu mengorganisasikan materi yang akan diajarkan dalam bentuk bahan ajar (Suwarni, 2015). Kemampuan guru dalam mengembangkan bahan ajar terkait dengan kompetensi pedagogik dan kompetensi professional. Guru sebagai pendidik profesional diharapkan memiliki kemampuan mengembangkan bahan ajar sesuai dengan mekanisme yang ada dengan memperhatikan karakteristik dan lingkungan sosial siswa. Bahan ajar yang mampu menampung keberagaman kemampuan dengan karakteristiknya serta mengaktifkan siswa menjadi suatu keharusan saat ini. Karena bahan ajar merupakan komponen terpenting untuk menentukan keberhasilan pembelajaran yang harus dipersiapkan guru sebelum melaksanakan kegiatan pemebelajaran di dalam kelas (Lestari, 2013).

Guru bertugas untuk menjabarkan materi pokok menjadi bahan ajar yang lengkap. Pengembangan bahan ajar penting dilakukan oleh guru agar pembelajaran lebih efektif, efisien, dan tidak melenceng dari kompetensi yang akan dicapainya. Bahan ajar yang dikembangkan tersebut harus bahan ajar yang bisa mengkonstruksi pengetahuan dalam diri siswa dan juga dikaitkan dengan konteks kehidupan nyata siswa. Suatu bahan ajar jika diperhatikan dapat mempengaruhi kemampuan siswa dalam pembelajaran karena tidak terlepas dari ketentuan yang diterapkan dalam bahan ajar tersebut (Prastowo, 2012).

Bahan ajar yang efektif adalah bahan ajar yang bisa memotivasi siswa dan mampu membuat siswa mengkonstruk sendiri konsepnya. Salah satu bahan ajar yang harus dikembangkan oleh guru yang dapat membuat siswa mengkonstruk sendiri konsepnya adalah bahan ajar berbasis metakognisi. Bahan ajar ini harus mampu membuat siswa menggunakan proses berpikirnya untuk; (1) memecahkan masalah melalui pengumpulan fakta-fakta, analisis informasi, menyusun berbagai alternatif pemecahan, dan memilih pemecahan masalah yang paling efektif; (2) memilih suatu keputusan yang terbaik dari beberapa pilihan yang ada melalui pengumpulan informasi, perbandingan kebaikan dan kekurangan dari setiap alternatif, analisis informasi, dan pengambilan keputusan yang terbaik berdasarkan alasan-alasan yang rasional; (3) menganalisis argumen dan memberikan interpretasi berdasarkan persepsi yang sahih melalui logical reasoning, analisis asumsi dan bias dari argumen, dan interpretasi logis; (4) menghasilkan suatu 
ide yang baru, konstruktif, dan baik berdasarkan konsepkonsep, dan prisnip-prinsip yang rasional maupun persepsi, dan intuisi individu (Pannen \& Melati, 1997).

Konsep dalam pembelajaran IPA mengutamakan keaktifan siswa untuk membangun pengetahuannya sendiri, membandingkan informasi baru dengan pemahaman yang telah dimiliki, dan menggunakan semua pengetahuan atau pengalaman untuk belajar melalui perbedaan-perbedaan yang ada pada pengetahuan baru dan lama untuk mencapai pemahaman baru.

Dalam kurikulum 2013 lebih tegas menekankan perubahan paradigma pendidikan, yaitu perubahan dari paradigma behavioristik menjadi paradigma konstruktivistik. Paradigma konstruktivistik menekankan pada refleksi diri dan pembentukan pengetahuan yang memiliki konstribusi bagi perkembangan keterampilan-keterampilan metakognitif. Strategi pembelajaran konstruktivistik terbukti dapat mendorong atau memberdayakan perkembangan keterampilan metakognitif. Strategi pembelajaran konstruktivistik sudah banyak disosialisasikan dan diintegrasikan ke dalam kurikulumkurikulum terbaru: namun, kenyataan kegiatan pembelajaran di lingkungan sekolah tidaklah demikian (Riyanto, 2014).

Sebagian besar guru masih banyak yang menekankan pada pemberian materi saja dan kurang memperhatikan proses bagaimana informasi tersebut diterima oleh siswa. Para guru masih kurang memahami aspek-aspek kualitas individu meliputi bakat, motivasi belajar dan kemampuan awal yang dimiliki siswa; dengan mengetahui aspek-aspek tersebut seorang guru dapat menata pembelajaran khususnya komponen-komponen strategi pembelajaran agar sesuai dengan karakteristik individu siswa (Purwandari, 2019).

Masih banyak guru yang belum mampu mengembangkan bahan ajar. Walaupun mampu, bahan ajar yang mereka kembangkan kurang efektif dalam pembelajaran. Berdasarkan observasi peneliti terhadap beberapa guru IPA di Kota Mataram, banyak guru yang belum mengembangkan bahan ajar IPA dan banyak guru yang belum paham cara mengembangkan bahan ajar yang efektif. Berdasarkan wawancara kepada beberapa guru kimia di Lombok Barat didapatkan bahwa sebagian besar guru kimia masih kesulitan dalam mengembangkan bahan ajar berbasis metakognitif. Hal ini disebabkan karena mereka sudah merasa cukup dengan bahan ajar biasa. Selain itu, mereka juga belum pernah mempelajari cara mengembangkan instrumen tersebut (Wildan dkk., 2019; Wildan dkk., 2019).

Berdasarkan hal tersebut, pelaksana tertarik untuk melakukan sosialisasi dan pendampingan pengembangan bahan ajar berbasis metakognitif untuk mahasiswa magister pendidikan IPA universitas mataram. Kegiatan ini merupakan bentuk intervensi dalam upaya meningkatkan kemampuan metakognisi siswa. 
Paparkan masalah yang dikaji, diakhiri dengan menjelaskan tujuan dan urgensi pengabdian. Empat poin penting yang wajib ada dalam pendahuluan adalah menguraikan secara jelas tentang (secara berurutan): (1) sedikit latar belakang umum kajian; (2) state of the art (kajian review literatur singkat) pengabdian-pengabdian dan pengabdian-pengabdian sebelumnya (yang mirip) untuk menjustifikasi novelty artikel yang dibuat; (3) gap analysis atau pernyataan kesenjangan (orisinalitas) atau kebaruan (novelty statement) atau beda unik pengabdian ini dibanding pengabdian-pengabdian sebelumnya atau berdasarkan state of the art (dari sisi penting tidaknya pengabdian serta perbandingan keunikan dengan pengabdian sebelumnya); cara pendekatan penyelesaian masalah (jika ada); (4) hasil yang diharapkan atau tujuan pengabdian. Bagian isi makalah ditulis dengan font Century Schoolbook dengan ukuran tulisan 11pt dan spasi 1.15 .

\section{METODE PELAKSANAAN}

Untuk mencapai target, maka ada beberapa tahapan implementasi program pengbadian yang dilakukan yaitu:

a. Tahap Persiapan. Beberapa kegiatan yang dilakukan pada tahapan ini meliputi: menyusun ToR (Term of Reference), identifikasi calon peserta, workshop internal tim pengabdian (seperti penentuan waktu pelatihan, tempat, materi pelatihan), pengurusan izin melaksanakan kegiatan pengabdian.

b. Tahap sosialisasi. Kegiatan yang dilakukan pada tahapan ini antara lain memberikan sosialisasi kepada mahasiswa magister IPA Unram. Materi yang dibahas yaitu cara pengembangan bahan ajar berbasis metakognisi.

c. Tahap pendampingan. Pada tahap ini dilakukan pendampingan terhadap kerja kelompok mahasiswa dalam menyelesaikan tugas berkaitan dengan pengembangan bahan ajar berbasis metakognisi.

d. Workshop hasil kerja guru. Pada tahap ini dilakukan workshop untuk melihat hasil kerja guru-guru berkaitan dengan pengembangan bahan ajar berbasis metakognisi.

e. Tahap Monitoring, Evaluasi dan Pelaporan. Kegiatan pada tahapan ini dimaksudkan untuk mendeteksi dan mengevaluasi keseluruhan kegiatan pengabdian sehingga dapat diketahui hasil, teridentifikasi permasalahan/kendala yang muncul, faktor yang mendukung dan menghambat serta solusi pemecahannya. Keseluruhan kegiatan selanjutnya dibuat dalam bentuk laporan akhir kegiatan pengabdian.

\section{HASIL DAN PEMBAHASAN}

\subsection{Deskripsi Pelaksanaan Kegiatan}

Kegiatan sosialisasi Pengembangan bahan ajar berbasis metakognisi ini dilaksanakan selama sehari, pada hari Selasa, tanggal 28 Oktober 2020 melalui zoom meeting, diikuti oleh 36 orang mahasiswa S-2 Pendidikan Sains Universitas Mataram, dan dihadiri oleh semua anggota tim.

Kegiatan diawali pada jam 09.00 dengan acara pembukaan yang disampaikan oleh Ketua Tim (Dr. H. Wildan). Pada acara pembukaan tersebut disampaikan tentang latar 
belakang, tujuan, manfaat, dan rangkaian acara pada kegiatan sosialisasi/pendampingan. Acara dilanjutkan dengan penyanjian materi yang pertama, yaitu Tinjauan filosofis metakognisi oleh Ketua Tim. Adapun pokok materinya meliputi hakikat manusia, hierarki kebutuhan menurut Maslow, dan kesadaran diri.

Kegiatan selanjutnya adalah penyampaian materi dan diskusi tentang tinjauan metakognisi yang dipandu oleh Drs. I Nyoman Loka, M.Si. Adapun pokok-pokok materinya meliputi komponen metakognisi, kemampuan metaognisi, regulasi metakognisi, pengetahuan tentang kognisi, regulasi kognisi, metamemory, dan metakomprehensi. Pada materi ini, peserta diminta mendiskusikan contoh-contoh dari materi yang dijelaskan sebelumnya. Diskusi berlangsung aktif dengan ditandai banyaknya peserta yang ingin menjelaskan hasil diskusi.

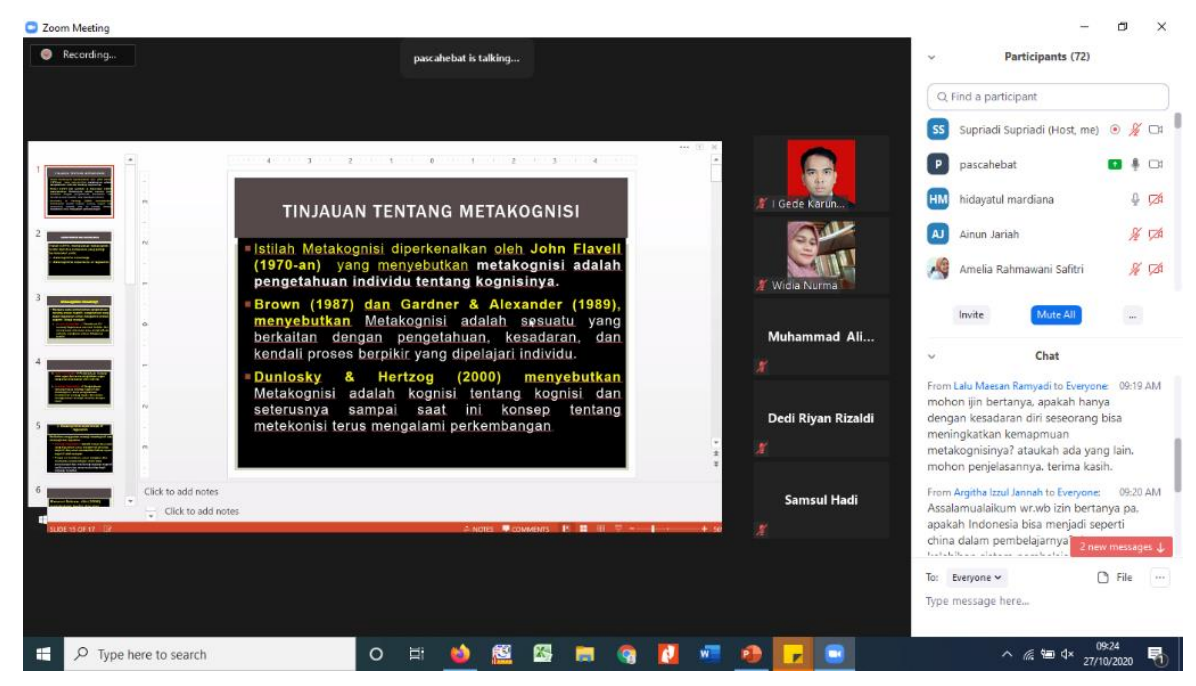

Gambar 1. Pemaparan materi tentang tinjauan metakognisi

Pada sesi ketiga, materi yang disampaikan adalah tentang pendekatan keterampilan metakognitif dalam pembelajaran sains di kelas dan pengembangan bahan ajar yang mampu mengembangkan kemampuan metakognisi. Materinya berisi tentang sintaks pembelajaran, metode penilaian metakognisi sains, hambatan dalam penerapan pendekatan keterampilan metakognitif, dan metode pengembangan bahan ajar berbasis metakognitif. Pada awalnya peserta diminta menjawab suatu soal dengan meminta mereka menentukan strategi, melaksanakan strategi, dan mengevaluasi diri sendiri terkait jawaban yang mereka sendiri. Mahasiswa selanjutnya diminta mendiskusikan cara mengembangkan bahan ajar berbasis metakognisi pada satu sub materi yang dipilih sendiri. 


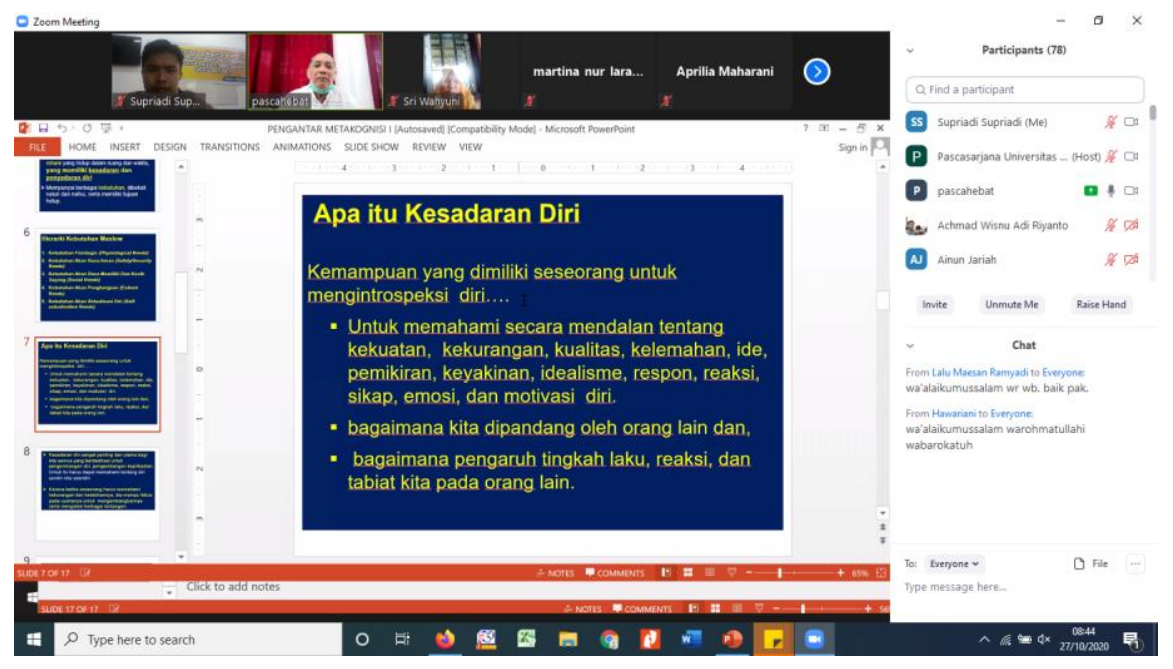

Gambar 2. Pemaparan materi sesi ketiga

\subsection{Evaluasi Hasil}

Sebelum acara selesai, dilakukan evaluasi untuk mengetahui tanggapan peserta terhadap kegiatan sosialisasi/pendampingan dan evaluasi pembelajaran untuk mengetahui penerimaan peserta terhadap kegiatan tersebut. Instrumen yang digunakan berupa kuesioner yang terdiri dari 5 (lima) komponen, yaitu (1) materi sosialisai, (2) hasil, (3) tindak lanjut, (4) fasilitator, (5) waktu pelaksanaan, dan Konsumsi. Gambaran kegiatan sosialisasi/ pendampingan tertera pada tabel berikut.

Tabel 1. Hasil Evaluasi Sosialisasi

\begin{tabular}{lll}
\hline Komponen & Indikator & Nilai \\
\hline 1.Materi & 1. Kejelasan dan Kemudahan diikuti & $\mathbf{2 . 8 3}$ \\
& a. Tinjauan filosofis metakognisi & 2.93 \\
& b. Pembelajaran berbasis metakognisi & 2.89 \\
& c. Pengembangan bahan ajar berbasis & 2.67 \\
& metakognisi & \\
& 2. Manfaat materi bagi peserta & $\mathbf{2 . 8 1}$ \\
& a. Tinjauan filosofis metakognisi & 2.89 \\
& b. Pembelajaran berbasis metakognisi & 2.89 \\
& c. Pengembangan bahan ajar berbasis & 2.67 \\
& metakognisi & \\
2. Hasil & 3. Menambah pemahaman tentang Materi: & $\mathbf{2 . 8 5}$ \\
& a. Tinjauan filosofis metakognisi & 2.92 \\
& b. Pembelajaran berbasis metakognisi & 2.85 \\
3. Tindak & c.Pengembangan bahan ajar berbasis metakognisi & 2.79 \\
Lanjut & 4. Mempelajari/berlatih lebih lanjut tentang & $\mathbf{2 . 7 0}$ \\
& materi: & \\
& a. Tinjauan filosofis metakognisi & 2.78 \\
& b. Pembelajaran berbasis metakognisi & 2.70 \\
& c. Pengembangan bahan ajar berbasis & 2.63 \\
& metakognisi & \\
4. Fasilitator & 5. Kemampuan dan Penampilan & $\mathbf{2 . 8 9}$ \\
& a. Kemampuan/penguasaan materi & 2.90 \\
& b. Penampilan & 2.88 \\
5. Waktu & 6. Waktu/lama kegiatan & $\mathbf{2 . 7 8}$ \\
\hline
\end{tabular}




\begin{tabular}{ll} 
a. Waktu pelaksanaan (hari libur) & 2.80 \\
b. Lama pelaksanaan (sehari_- & 2.76 \\
Rata-rata & $\mathbf{2 . 8 3}$ \\
\hline
\end{tabular}

Dari tabel 1 di atas dapat diketahui bahwa skor penilaian secara keseluruhan 2,83 pada rentangan skor 1 (kurang baik) - 3 (sangat baik). Dari hasil tersebut dapat disimpulkan bahwa kegiatan sosialisasi dan pendampingan pengembangan bahan ajar IPA berbasis metakognisi masuk dalam katagori sangat baik.

Pada komponen materi yang terdiri dari 2 (dua) indikator yaitu kejelasan dan manfaat materi bagi peserta. Untuk kejelasan materi yang terdiri dari 3 butir pernyataan sebagian besar menjawab pada skala 3 (sangat baik) dengan nilai rata-rata 2,83. Demikian juga dengan indikator manfaat materi, nilai rata-rata 2.81. Berdasarkan hal tersebut ketiga materi meliputi (a) tinjauan filosofis metakognisi, (b) pembelajaran berbasis metakognisi, dan (c) pengembangan bahan ajar berbasis metakognisi sangat jelas dan mudah dipahami dan sangat bermanfaat bagi mereka. Materi pengembangan bahan ajar berbasis metakognisi tersebut bagi sebagian peserta sudah sangat familiar, karena sebagian peserta adalah guru yang sudah sering mendapatkan informasi baik melalui kuliah maupun pelatihan.

Hasil evaluasi pada komponen tindak lanjut dari kegiatan sosialisasi/pendampingan diperoleh nilai rata-rata 2.70 pada rentangan nilai $1-3$. Hasil ini menunjukkan bahwa peserta mempunyai niat dan tekad untuk berlatih dalam bahan ajar IPA berbasis metakognisi pada bidang studinya masing-masing. Dengan kata lain peserta bersikap positif terhadap materi-materi yang disempaikan pada kegiatan sosialisai/pendampingan. Demikian pula penilaian peserta terhadap komponen lain, seperti kemampuan dan penampilan fasilitator, waktu pelaksanaan dan lama pelaksanaan, konsumsi dan lainnya. Di antara komponen tersebut, komponen waktu dan lama kegiatan memperoleh nilai paling rendah dibandingkan komponen yang lain. Hal tersebut dapat dipahami karena pelaksanaan kegiatan dilakukan sehari (dan dilaksanakan pada waktu hari libur di kampus.

Terkait dengan indikator kemampuan dan penampilan narasumber, skor rata-rata 2,89, termasuk dalam katagori sangat mampu dan berpanampilan sangat baik, karena narasumber telah mempersiapkan materi dengan baik dengan power point yang menarik, dibantu handout. Mengenai waktu pelaksanaan juga demikian. Skor rata-rata 2,78 relatif lebih rendah penilaian peserta, terutama pada lama pelaksanaan yang hanya sehari. Dengan kata lain bila kegiatan sejenis dilakukan perlu waktu yang panjang panjang, minimal 2 (dua) hari.

\subsection{Faktor Pendukung}

Kegiatan sosialisasi dan pendampingan ini berjalan dengan baik karena didukung oleh beberapa faktor: 1) Antusiasme peserta yang ditunjukkan oleh kesediaan mengikuti 
kegiatan sampai akhir pada hari libur; 2) Kesiapan pengelola Program Studi S-2 IPA Unram memfasilitasi kegiatan ini dengan menugaskan staf administrasi; 3) Ketersediaan sarana dan prasarana yang memadai terutama sumber belajar yang dapat di akses dengan mudah melalui internet. 4) Semua anggota tim peneliti hadir tepat waktu sehingga kegiatan ini dapat berjalan dengan baik.

\subsection{Faktor Penghambat}

Secara umum tidak ada faktor penghambat dalam kegiatan yang telah dilangsungkan, kecuali masalah keterbatasan waktu yang ditujukkan oleh evaluasi kegiatan.

\section{SIMPULAN}

Berdasarkan hasil tersebut di atas dapat disimpulkan bahwa (1) Kegiatan sosialisasi dan pendampingan pengembangan bahan ajar berbasis metakognisi berjalan dengan baik dan lancar sesuai perencanaan; (2) Hasil kegiatan sangat positif bagi peserta, baik materi sosialisasi/pendampingan, pemahaman, kegunaan dan tindak lanjut yang akan dilakukan peserta. (3) Kendala peserta dalam menerapkan pengembangan bahan ajar berbasis metakognisi bagi guru antara lain kemampuan yang masih belum mencukupi dan beban tugas administrasi yang tinggi dan beban tugas mengajar yang cukup padat. (4) Saran untuk kegiatan sejenis terutama terkait dengan waktu dan lama pelaksanaan yang perlu diperpanjang minimal 2 (dua) hari.

\section{UCAPAN TERIMA KASIH}

Penulis mengucapkan terima kasih kepada Universitas Mataram yang telah mendanai kegiatan pengabdian ini.Pengakuan harus ditulis secara singkat dan jelas. Selain itu, hindari pengakuan hiperbola.

\section{REKOMENDASI}

Perlu dilakukan juga sosialisasi pengembangan bahan ajar berbasis multi level representasi agar bahan ajar siswa lebih beragam.

\section{REFERENSI}

Hernawan, A. H., Permasih, H., \& Dewi, L. (2012). Pengembangan Bahan Ajar. Direktorat UPI.

Kelana, J. B., \& Pratama, D. F. (2019). Bahan ajar IPA Berbasis Literasi Sains. Lekkas.

Lestari, I. (2013). Pengembangan Bahan Ajar Berbasis Kompetensi. Akademia.

Pannen, P., \& Melati. (1997). Mengajar di Perguruan tinggi Bagian Dua Pendidikan Orang Dewasa. Direktorat Jendral Pendidikan Tinggi Departemen Pendidikan dan Kebudayaan.

Prastowo, A. (2012). Panduan Kreatif Membuat Bahan Ajar Inovatif. DIVA Press.

Purwandari, N. (2019). Keterampilan Metakognitif Pada Pembelajaran IPA Biologi di Kalangan Siswa SMP Kota Blitar. 
Ramdoniati, N., Muntari, \& Hadisaputra, S. (2019). Pengembangan Bahan Ajar Kimia Berbasis Problem Based Learning Untuk Meningkatkan Keterampilan Metakognisi. Jurnal Penelitian Pendidikan IPA, 5(1), 27-33.

Riyanto, H. Y. (2014). Paradigma Baru pembelajaran: Sebagai referensi bagi pendidik dalam Implementasi Pembelajaran yang Efektif dan berkualitas. Prenada Media.

Suwarni, E. (2015). Pengembangan buku ajar berbasis lokal materi keanekaragaman laba-laba di Kota Metro sebagai sumber belajar alternatif biologi untuk siswa SMA Kelas X. , 6(2). Bioedukasi, 6(2).

Wildan, W., Hakim, A., \& Supriadi, S. (2019). Pengembangan Perangkat Pembelajaran IPA Berbasis Lingkungan Untuk Siswa SMP/MTs. Jurnal Ilmiah Profesi Pendidikan, 3(2), 298760.

(2018). Sosialisasi dan Pendampingan Siswa Madrasah Aliyah Negeri I Mataram Dalam Mengurangi Laju Pemanasan Global Tahun 2017. Jurnal Pendidikan dan Pengabdian Masyarakat, 1(1).

Wildan, W., Hakim, A., Laksmiwati, D., \& Supriadi, S. (2019). Sosialisasi Perangkat Pembelajaran Berbasis Lingkungan untuk Guru IPA SMP/MTS di Lombok Barat Dalam Upaya Mengurangi Laju Pemanasan Global. Jurnal Pendidikan dan Pengabdian Masyarakat, 2(1).

Wildan, W., Hakim, A., Laksmiwati, D., Savalas, L. R. T., \& Supriadi, S. (2019). Sosialisasi dan Pendampingan Pengembangan Instrumen Hasil Belajar Berbasis Ketrampilan Berpikir Tingkat Tinggi (HOTS) pada Mahasiswa Magister Pendidikan IPA Universitas Mataram. Jurnal Pengabdian Magister Pendidikan IPA, 2(2). 